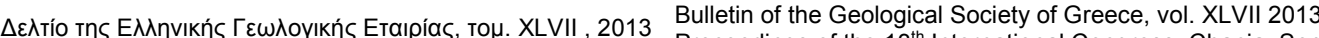
Proceedings of the $13^{\text {th }}$ International Congress, Chania, Sept.

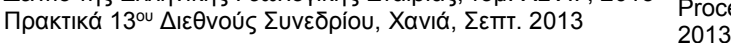

\title{
TRACE ELEMENT CONTENT AND MORPHOLOGICAL CHARACTERISTICS IN MICROSCALE OF COMMERCIALLY AVAILABLE CLAYS USED AS COSMETIC PRODUCTS
}

\author{
Giouri K. ${ }^{1}$, Papadopoulos A. ${ }^{1}$, Bourliva A. ${ }^{1}$, Tzamos E. ${ }^{1}$, \\ Papadopoulou L. ${ }^{1}$ and Filippidis A. ${ }^{1}$ \\ ${ }^{1}$ Aristotle University of Thessaloniki, School of Geology, Department of Mineralogy-Petrology- \\ EconomicGeology,agiouri@geo.auth.gr,argpapad@geo.auth.gr,annab@geo.auth.gr, \\ tzamos@geo.auth.gr,lambrini@geo.auth.gr,anestis@geo.auth.gr
}

\begin{abstract}
Two kinds of clays (one white and one green) available in pharmacies and herbalist's shops in the Greek market have been studied for their concentrations in trace elements, namely $\mathrm{As}, \mathrm{Be}, \mathrm{Cd}, \mathrm{Cr}, \mathrm{Hg}, \mathrm{Ni}, \mathrm{P}, \mathrm{Pb}, \mathrm{Sb}, \mathrm{Se}, \mathrm{Te}, \mathrm{Tl}$ and $\mathrm{Zr}$. According to EC Regulation 1223/2009, the presence of the analyzed trace elements and their compounds, are prohibited in cosmetics. The most abundant trace elements of the white clay are $\mathrm{P}$ (330 ppm), Pb (220 ppm) and $\mathrm{Zr}(11 \mathrm{ppm})$, while for the green clay are $\mathrm{P}$ (1250 ppm), As (43 ppm), Cr (31 ppm), $\mathrm{Pb}(30 \mathrm{ppm})$ and $\mathrm{Ni}$ (23 ppm). Compared to the global shale average concentration of elements, $\mathrm{Pb}$ is enriched 11-times in the white clay and As is enriched 3-times in the green clay. The depleted trace elements of the white clay are $\mathrm{As}, \mathrm{Cd}, \mathrm{Cr}, \mathrm{Hg}, \mathrm{Ni}, \mathrm{P}, \mathrm{Sb}, \mathrm{Se}, \mathrm{Te}, \mathrm{Tl}$ and $\mathrm{Zr}$, while of the green one are $\mathrm{Cr}, \mathrm{Hg}, \mathrm{Ni}, \mathrm{Sb}, \mathrm{Te}$, Tl and $\mathrm{Zr}$. Concerning the morphological characteristics, differences were observed in the particle size and shape between the white and green clay aggregates.

Key words: Industrial minerals, Microporous natural raw materials, Inorganic contaminants.
\end{abstract}

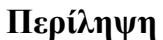

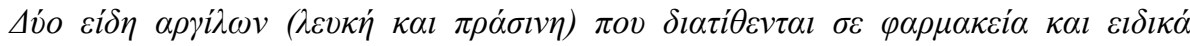

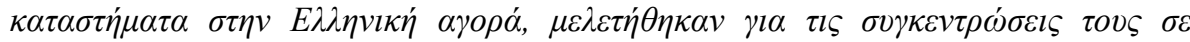

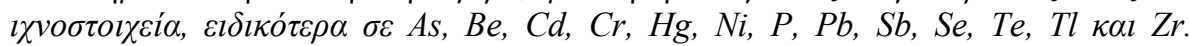

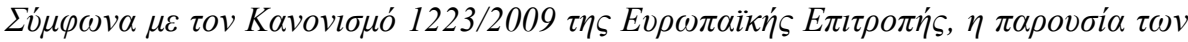

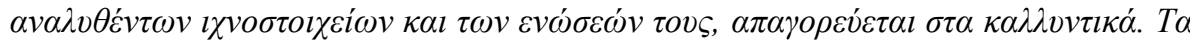

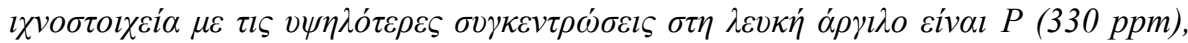

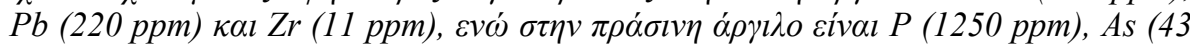

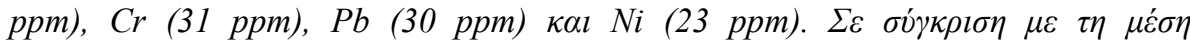

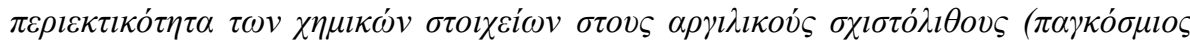

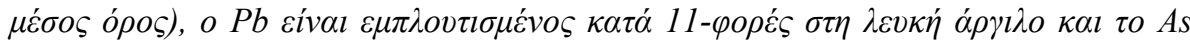

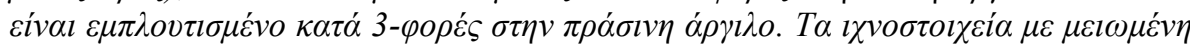

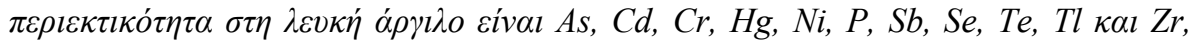

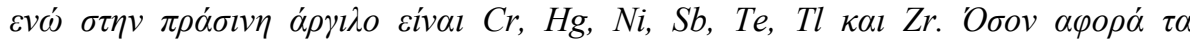




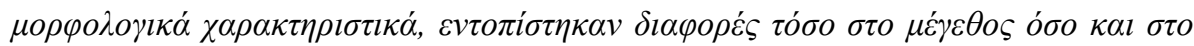

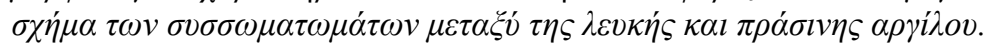

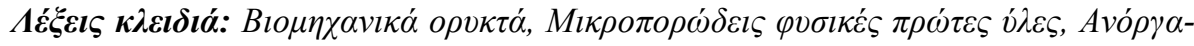
vol $\rho v \pi \alpha \nu \tau \dot{\varepsilon} \varsigma$.

\section{Introduction}

Cosmetic products are designed to be placed in contact with external parts of the human body. In these cases they require a consistency suitable for application. Because of their high specific surface area, optimum rheological characteristics and/or excellent sorptive capacity which are being studied by many researchers, clay minerals have been used in several health care formulations (Patel et al., 1986; Christidis et al., 2006; López-Galindo et al., 2007; Viseras et al., 2007; Rathossi et al., 2011; Christidis, 2012). This is because when dispersed in polar solvents, they possess enough viscosity to remain in contact with the application area (Murray, 2000; Carretero, 2002; Silva et al., 2011).

In order to be suitable for topical application, clays must comply with a number of compositional requirements (Galán et al., 1985; López-Galindo and Viseras, 2004). Specifically, they must have low or zero toxicity. Their high adsorption capacity can cause the accumulation of trace elements and some of them are considered as potentially toxic (López-Galindo et al., 2007; Silva et al., 2011). Cosmetics content in European Community is regulated, with EEA relevance, by the EU Regulation 1223/2009-a simplification of the Council Directive 76/768/EEC (EC 2009).

Cosmetic clays are available in various colours (white, green, red, pink, yellow etc.), which reflect differences in mineralogical and organic content. In the present study, white and green clays being commercially available in the Greek market were analysed for their content of $\mathrm{As}, \mathrm{Be}, \mathrm{Cd}, \mathrm{Cr}, \mathrm{Hg}$, $\mathrm{Ni}, \mathrm{P}, \mathrm{Pb}, \mathrm{Sb}, \mathrm{Se}, \mathrm{Te}, \mathrm{Tl}$ and $\mathrm{Zr}$. Moreover, morphological characteristics were also determined.

\section{Materials and Methods}

Two commercial cosmetic clays available in pharmacies and herbalist's shops in the Greek market were studied. The samples were studied in their bulk form, as they were already available in powder.

\subsection{Sample Identification}

According to their colour which is probably affected by the mineralogical composition and organic matter, the clays analysed were classified according to their commercial names in two kinds: white (WC1) and green (GC1).

\subsection{Chemical Analyses}

The chemical analyses were performed at the Acme Analytical Laboratories (Vancouver, Canada). Trace elements in the clays were extracted using the aqua regia digestion, while their concentrations were determined in all samples by ICP-MS. The elements analysed were selected because their occurrence, as well as their compounds, are excluded in cosmetic ingredients, including clays, by the EU Regulation 1223/2009.

\subsection{Morphology}

The morphology of the clays in microscale was evaluated with a JEOL J.S.M. 840A scanning electron microscope at the Scanning Microscope Laboratory, Aristotle University of Thessaloniki. The samples were coated with carbon - average thickness of $200 \AA$ - using a vacuum evaporator JEOL-4X. 


\section{Results and Discussion}

The health impact of the presence of several trace elements in the natural environment is potentially heavy. Cosmetic clays are commercial products based on natural raw materials, thus they must comply with several regulations concerning their chemical composition. According to EU Regulation 1223/2009, the presence of As, Be, Cd, Cr, Hg, Ni, P, Pb, Sb, Se, Te, Tl, Zr and their compounds in cosmetic ingredients, including clays must be excluded (Table 1).

Table 1 - Some of the trace elements that occur in the list of substances prohibited in cosmetic products, according to EC Regulation 1223/2009, ANNEX II (EC 2009).

\begin{tabular}{|c|l|}
\hline Reference Number & \multicolumn{1}{|c|}{ Chemical Name / INN } \\
\hline $\mathbf{4 0}$ & Sb and its compounds \\
\hline $\mathbf{4 3}$ & As and its compounds \\
\hline $\mathbf{5 4}$ & Be and its compounds \\
\hline $\mathbf{6 8}$ & Cd and its compounds \\
\hline $\mathbf{9 7}$ & Cr, chromic acid and its salts \\
\hline $\mathbf{2 2 1}$ & $\begin{array}{l}\text { Hg and its compounds, except those special cases included in Annex } \\
\text { V }\end{array}$ \\
\hline $\mathbf{2 7 9}$ & P and metal phosphides \\
\hline $\mathbf{2 8 9}$ & Pb and its compounds \\
\hline $\mathbf{2 9 7}$ & $\begin{array}{l}\text { Se and its compounds with the exception of selenium disulphide un- } \\
\text { der the conditions set out under reference No 49 in Annex III }\end{array}$ \\
\hline $\mathbf{3 1 2}$ & Te and its compounds \\
\hline $\mathbf{3 1 7}$ & Tl and its compounds \\
\hline $\mathbf{3 9 1}$ & $\begin{array}{l}\text { Zr and its compounds, with the exception of the substances listed un- } \\
\text { der reference number 50 in Annex III, and the zirconium lakes, pig- } \\
\text { ments or salts of the colouring agents when listed in Annex IV }\end{array}$ \\
\hline $\mathbf{1 0 9 3}$ & Nickel \\
\hline
\end{tabular}

Significant concentrations of the trace elements mentioned above have been measured in the white and green clay samples (Table 2 and Figure 1). The investigated clays contain 1.2 and $43.2 \mathrm{ppm}$ As (corresponding for white and green respectively), 1.9 and $3.0 \mathrm{ppm} \mathrm{Be},<0.01$ and $0.27 \mathrm{ppm} \mathrm{Cd}$, 0.7 and $31.1 \mathrm{ppm} \mathrm{Cr},<5$ and $17 \mathrm{ppb} \mathrm{Hg}, 0.5$ and $23.1 \mathrm{ppm} \mathrm{Ni}, 330$ and $250 \mathrm{ppm} \mathrm{P,} 220.10$ and $30.10 \mathrm{ppm} \mathrm{Pb}, 0.33$ and $0.20 \mathrm{ppm} \mathrm{Sb},<0.1$ and $0.4 \mathrm{ppm} \mathrm{Se},<0.02$ and $0.03 \mathrm{ppm} \mathrm{Te}, 0.23$ and 0.47 ppm Tl, 10.6 and 0.6 ppm Zr.

In general, green clay contains higher concentrations than the white clay in all trace elements, apart from $\mathrm{Pb}, \mathrm{Sb}$ and $\mathrm{Zr}$. The most abundant trace elements of the white clay are $\mathrm{P}(330 \mathrm{ppm}), \mathrm{Pb}$ $(220 \mathrm{ppm})$ and $\mathrm{Zr}(11 \mathrm{ppm})$, while for the green clay are P (1250 ppm), As (43 ppm), Cr (31 ppm), $\mathrm{Pb}(30 \mathrm{ppm})$ and $\mathrm{Ni}(23 \mathrm{ppm})$.

Compared to the average concentration of elements in shales (Shale average) (Turekian \& Wedepohl, 1961 and Mason \& Moore, 1982) Pb is enriched 11-times in the white clay and As is enriched 3-times in the green clay. When the ratio of an element concentration to that of Shale average is $>2$ the element is considered to be enriched and when it is $<0.5$, is considered to be depleted. The depleted trace elements of the white clay are As, Cd, Cr, Hg, Ni, P, Sb, Se, Te, Tl and $\mathrm{Zr}$, while for the green one are $\mathrm{Cr}, \mathrm{Hg}, \mathrm{Ni}, \mathrm{Sb}, \mathrm{Te}, \mathrm{Tl}$ and $\mathrm{Zr}$.

XLVII. No $2-814$ 
Concerning morphological characteristics in microscale, the white clay (WC1) consists of small aggregates of flaky microparticles (Figure 2a). Single aggregates have a size of about $25 \mu \mathrm{m}$. The green clay (GC1) shows a different morphology (Figure 2b). It consists of globular aggregates with sizes that exceed $50 \mu \mathrm{m}$ in diameter. However, it appears to be formed by platy particles, similar to the ones observed in the white clay. Yet, Transmission Electron Microscopy (TEM) is able to provide more information concerning the real and detailed morphology of clays.

\section{Conclusions}

The chemical analysis of the samples revealed that they contain trace elements, whose presence is prohibited in cosmetic products.

Compared to the Shale average, the white clay is enriched in $\mathrm{Pb}$, while the green one is enriched in As. Both kinds of clays are depleted in $\mathrm{Cr}, \mathrm{Hg}, \mathrm{Ni}, \mathrm{Sb}, \mathrm{Te}, \mathrm{Tl}$ and $\mathrm{Zr}$. Moreover, the white one is also depleted in As, Cd, P, and Se.

Concerning morphological characteristics in microscale, white clay consist of small aggregates of flaky microparticles, while green clay consist of globular aggregates.

In any case, further investigation concerning the bioavailability of the trace elements determined in clays used in cosmetics, is essential.

Table 2 - Trace element content of the studied clay samples (Shale average after Turekian $\&$ Wedepohl, 1961 and Mason \& Moore, 1982).

\begin{tabular}{|l|l|c|c|c|c|c|c|}
\hline & & $\begin{array}{c}\text { Detection } \\
\text { Limit }\end{array}$ & WC1 & GC1 & $\begin{array}{c}\text { Shale Average } \\
\text { (SA) }\end{array}$ & WC1:SA & GC1:SA \\
\hline $\mathbf{A s}$ & $p p m$ & 0.1 & 1.2 & $\mathbf{4 3 . 2}$ & 13 & 0.09 & $\mathbf{3 . 3 2}$ \\
\hline $\mathbf{B e}$ & $p p m$ & 0.1 & 1.9 & 3.0 & 3 & 0.63 & 1.00 \\
\hline $\mathbf{C d}$ & $p p m$ & 0.01 & $<0.01$ & 0.27 & 0.3 & $<0.03$ & 0.90 \\
\hline $\mathbf{C r}$ & $p p m$ & 0.5 & 0.7 & $\mathbf{3 1 . 1}$ & 90 & 0.01 & 0.35 \\
\hline $\mathbf{H g}$ & $(\mathrm{ppb})$ & 5 & $<5$ & 17 & 400 & $<0.01$ & 0.04 \\
\hline $\mathbf{N i}$ & $p p m$ & 0.1 & 0.5 & $\mathbf{2 3 . 1}$ & 68 & 0.01 & 0.34 \\
\hline $\mathbf{P}$ & $p p m$ & 10 & $\mathbf{3 3 0}$ & $\mathbf{1 2 5 0}$ & 700 & 0.47 & 1.79 \\
\hline $\mathbf{P b}$ & $p p m$ & 0.01 & $\mathbf{2 2 0 . 1 0}$ & $\mathbf{3 0 . 1 0}$ & 20 & $\mathbf{1 1 . 0 1}$ & 1.51 \\
\hline $\mathbf{S b}$ & $p p m$ & 0.02 & 0.33 & 0.20 & 1.5 & 0.22 & 0.13 \\
\hline $\mathbf{S e}$ & $p p m$ & 0.1 & $<0.1$ & 0.4 & 0.6 & $<0.17$ & 0.67 \\
\hline $\mathbf{T e}$ & $p p m$ & 0.02 & $<0.02$ & 0.03 & 2.2 & $<0.01$ & 0.01 \\
\hline $\mathbf{T l}$ & $p p m$ & 0.02 & 0.23 & 0.47 & 1 & 0.23 & 0.47 \\
\hline $\mathbf{Z r}$ & $p p m$ & 0.1 & $\mathbf{1 0 . 6}$ & 0.6 & 160 & 0.07 & $<0.01$ \\
\hline
\end{tabular}



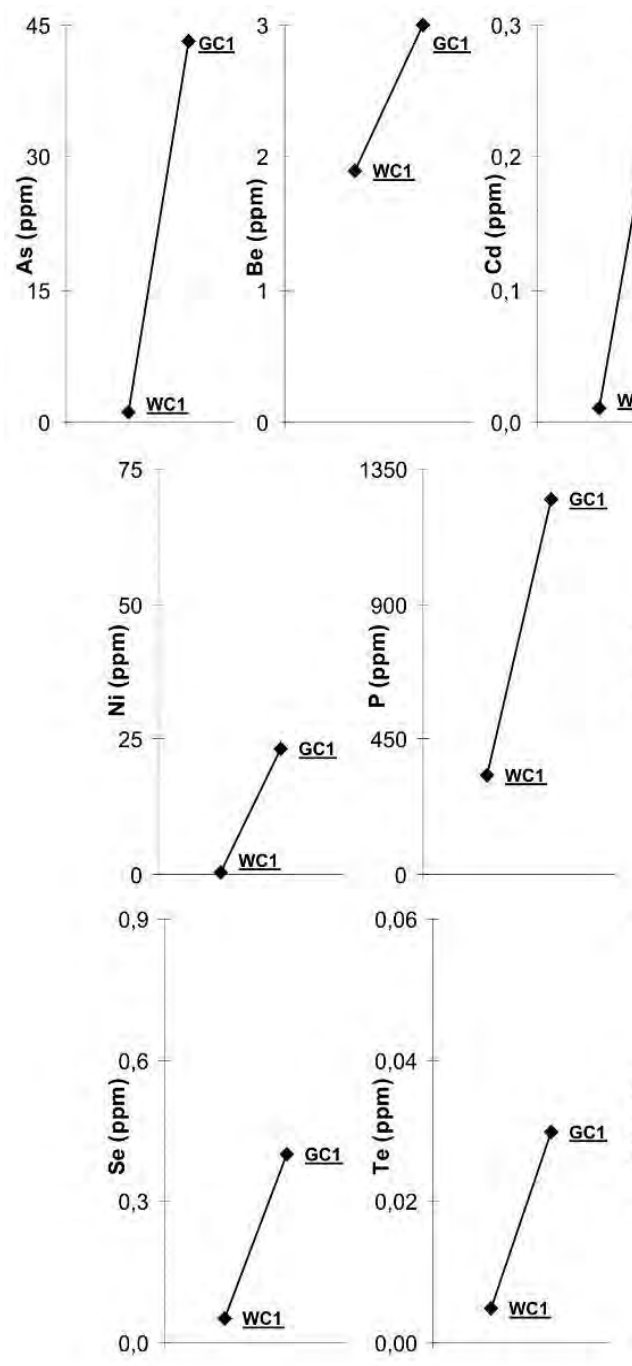
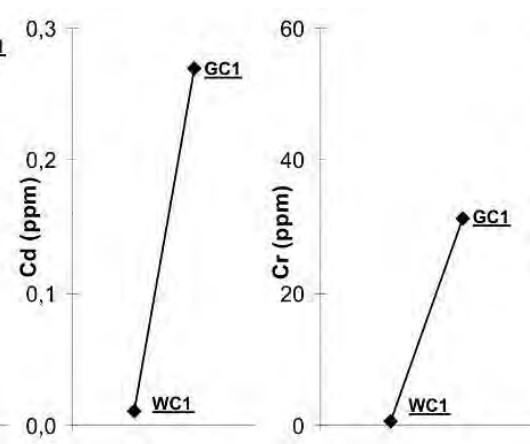

30

225

wC1

0,3
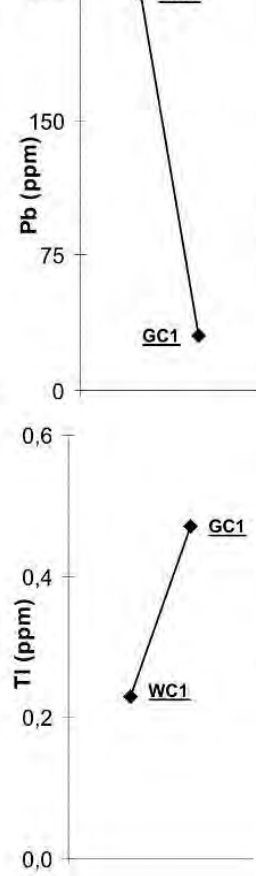

है

0

$\underline{\text { WC1 }}$

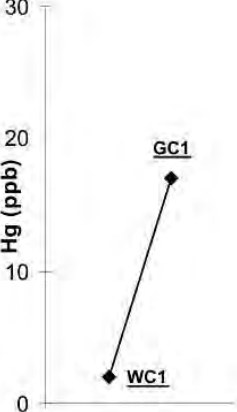

wC1

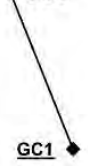

GC1

0,1

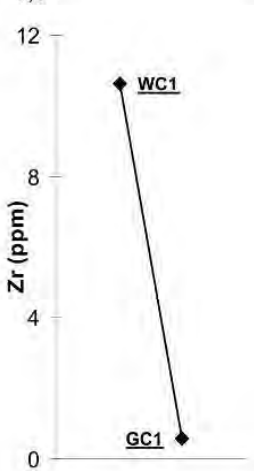

Figure 1 - Variation of trace elements concentrations among the studied samples.

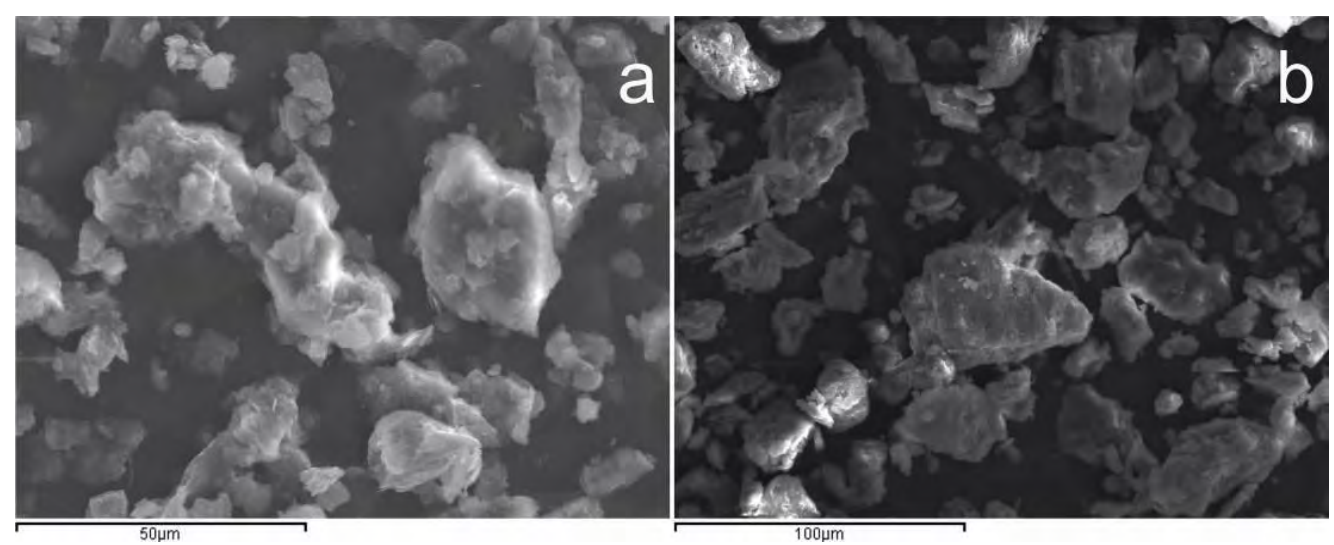

Figure 2 - SEM microphotographs of the studied samples. (a) White clay (WC1) and (b) Green clay (GC1). 


\section{References}

Carretero M.I. 2002. Clay minerals and their beneficial effects upon human health. A review, Appl. Clay Sci., 21, 155-163.

Christidis G.E. 2012. Assessment of Industrial Clays. In Bergaya F. et al. (eds): Handbook of Clay Science, 2nd edition, Elsevier, Amsterdam (in press).

Christidis G.E., Blum A.E. and Eberl D.D. 2006. Influence of layer charge and charge distribution of smectites on the flow behaviour and swelling of bentonites, Appl. Clay Sci., 34, 125138.

EC 2009. Regulation (EC) No 1223/2009 of the European parliament and of the Council of 30 November 2009 on Cosmetic products, Official Journal of the European Union, L342 (22.12.2009), 59-209.

Galán E., Liso M.J.and Forteza M. 1985. Minerales utilizados en la industria farmacéutica, Bol. Soc. Esp. Mineral., 8, 369-378.

López-Galindo A. and Viseras C. 2004. Pharmaceutical and cosmetic application of clays. In Wypych, F., Satyanarayana, K.G. (eds.), Clay Surfaces: Fundamentals and Applications, Elsevier Ltd, 267-289.

López-Galindo A., Viseras C. and Cerezo P. 2007. Compositional, technical and safety specifications of clays to be used as pharmaceutical and cosmetic products, Appl. Clay Sci., 36, 5163.

Mason B. and Moore C.B. 1982. Principles of Geochemistry, Wiley, New York, 344p.

Murray H.H. 2000. Traditional and new applications for kaolin, smectite, and palygorskite: a general overview, Appl. Clay Sci., 17, 207-221.

Patel N.K., Kennon L. and Levinson R.S. 1986. Pharmaceutical suspensions, In Lachman, L., Lieberman, H.A., Kanig, J.L. (eds.), The Theory and Practice of Industrial Pharmacy, 3rd ed., Lea and Febiger, Philadelphia, 479-501.

Rathossi C., Lambropoulou P., Skourlis K. and Katagas C. 2011. Mineralogical and microstructure of clay-bearing sediments of NE Peloponnese (Greece): Indices for physical and mechanical behaviour in civil engineering works, Clay Miner., 47 (2), 259-274.

Silva P.S.C., Oliveira S.M.B., Farias L., Fávaro D.I.T. and Mazzili B.P. 2011. Chemical and radiological characterization of clay minerals used in pharmaceutics and cosmetics, Appl. Clay Sci., 52, 145-149.

Turekian K.K. and Wedepohl K.H. 1961. Distribution of elements in some major of the earth's crust, Geol. Soc. Am. Bull., 72, 175-192.

Viseras C., Aguzzi C., Cerezo P. and Lopez-Galindo A. 2007. Uses of clay minerals in semisolid health care and therapeutic products, Appl. Clay Sci., 36, 37-50. 